\title{
Ocean acidification accelerates dissolution of experimental coral reef communities
}

\author{
S. Comeau, R. C. Carpenter, C. A. Lantz, and P. J. Edmunds \\ Department of Biology, California State University, 18111 Nordhoff Street, Northridge, CA 91330-8303, USA \\ Correspondence to: S. Comeau (steve.comeau@csun.edu)
}

Received: 27 June 2014 - Published in Biogeosciences Discuss.: 15 August 2014

Revised: 20 November 2014 - Accepted: 24 November 2014 - Published: 19 January 2015

\begin{abstract}
Ocean acidification (OA) poses a severe threat to tropical coral reefs, yet much of what is know about these effects comes from individual corals and algae incubated in isolation under high $p \mathrm{CO}_{2}$. Studies of similar effects on coral reef communities are scarce. To investigate the response of coral reef communities to OA, we used large outdoor flumes in which communities composed of calcified algae, corals, and sediment were combined to match the percentage cover of benthic communities in the shallow back reef of Moorea, French Polynesia. Reef communities in the flumes were exposed to ambient $(\sim 400 \mu \mathrm{atm})$ and high $p \mathrm{CO}_{2}(\sim 1300 \mu \mathrm{atm})$ for 8 weeks, and calcification rates measured for the constructed communities including the sediments. Community calcification was reduced by $59 \%$ under high $p \mathrm{CO}_{2}$, with sediment dissolution explaining $\sim 50 \%$ of this decrease; net calcification of corals and calcified algae remained positive but was reduced by $29 \%$ under elevated $p \mathrm{CO}_{2}$. These results show that, despite the capacity of coral reef calcifiers to maintain positive net accretion of calcium carbonate under OA conditions, reef communities might transition to net dissolution as $p \mathrm{CO}_{2}$ increases, particularly at night, due to enhanced sediment dissolution.
\end{abstract}

\section{Introduction}

The calcium carbonate framework produced by coral reefs hosts the highest known marine biodiversity and protects tropical shores from wave erosion (Ferrario et al., 2014). However, in recent decades coral reefs have been impacted by a diversity of disturbances, and now they are threatened by an increase in seawater temperature and ocean acidification (OA) (Hoegh-Guldberg et al., 2007; Kleypas and Yates,
2009). OA is caused by the dissolution of atmospheric $\mathrm{CO}_{2}$ in seawater, which reduces $\mathrm{pH}$, depresses carbonate ion concentration, and increases bicarbonate ion concentration with no change in total alkalinity (Feely et al., 2004). The net effects of OA on coral reefs remain unclear as most studies show a decrease in organismic calcification under OA conditions (Erez et al., 2011; Chan and Connolly, 2013), while recent laboratory work describes species-specific responses with some corals and calcifying algae resistant to decreasing pH (Comeau et al., 2013; Takahashi and Kurihara, 2013). Differential organismic sensitivities to OA potentially could lead to changes in coral community structure, and in turn this could affect habitat complexity (Fabricius et al., 2011, 2014).

Critically, most of the studies on coral reef organisms have been performed on individuals maintained in isolation in laboratory conditions, and studies performed at the scale of whole communities are scarce (Leclercq et al., 2002; Jokiel et al., 2008; Andersson et al., 2009; Dove et al., 2013). Generally there are three complementary approaches for studying the responses of coral reef communities to OA: firstly, in situ observations of communities living in naturally acidified water (Fabricius et al., 2011) due to volcanic activities or local conditions (Shamberger et al., 2014); secondly, carbonate chemistry can be manipulated directly in situ (Kline et al., 2012), although this approach is challenging technically and has not yet been used to study intact communities; and thirdly, reef communities can be constructed ex situ (Andersson et al., 2009; Dove et al., 2013) to allow precise control of the physical parameters predicted under future OA conditions. For our experiment, we chose to construct ex situ communities and used, for the first time, large outdoor flumes (after Atkinson and Bilger, 1992) to investigate the effects of OA on coral reef communities. 
In addition to corals and macroalgae, it is important to incorporate sediments in OA experiments, as this component of reef ecosystems may be sensitive to decreasing $\mathrm{pH}$ (Cyronak et al., 2013a, b; Andersson et al., 2009). Dissolution occurs on coral reefs in sediment pore-waters, or in particular microenvironments where $p \mathrm{CO}_{2}$ is elevated due to biological activity (Andersson and Gledhill, 2013). Observations in Bermuda have shown that the dissolution of $\mathrm{Mg}$-calcite sediments occurs in a location with seawater $p \mathrm{CO}_{2}$ naturally elevated to values expected by the end of the century (Andersson et al., 2007). Further, in situ manipulations show that elevated $p \mathrm{CO}_{2}(\sim 800 \mu \mathrm{atm})$ can transition the calcification budget of coral reef sediments from net precipitation to net dissolution (Cyronak et al., 2013a). Increasing $p \mathrm{CO}_{2}$ likely will lead to increasing dissolution and decreased precipitation of calcium carbonate, resulting in coral reef community calcification changing from net precipitation to net dissolution (Yates and Halley, 2006; Silvermann et al., 2009; Andersson et al., 2009). Given the aforementioned results that highlight the importance of sediments in the community calcification of entire coral reefs, we included reef carbonate sediments into the constructed communities.

We investigated the response of constructed reef communities in flumes to OA filled with seawater maintained either at ambient $p \mathrm{CO}_{2}$ (i.e., $\sim 400 \mu \mathrm{atm}$ ) or elevated $p \mathrm{CO}_{2}$. Net calcification rates were measured at three levels of biological function: whole community, sediments, and macrocalcifiers to determine the sensitivity to OA of each compartment of the community.

\section{Materials and methods}

\subsection{Collection and sample preparation}

This study was carried out in August-October 2013 in Moorea, French Polynesia, using organisms collected from the back reef of the north shore at $\sim 1-2$ m depth. The organisms used to construct communities in outdoor flumes were assembled to match the contemporary (in 2013) mean cover of a back reef in Moorea (Carpenter, 2014; Edmunds, 2014). Coral communities were built from the four dominant coral taxa found on the back reefs of Moorea: massive Porites spp. (11\% cover), Porites rus (6\%), Montipora spp. (3\%), and Pocillopora spp. (2\%), which together accounted for $98 \%$ of the coral cover in this habitat. In addition to corals, $6 \%$ of the planar floor surface of the flumes was covered by crustose coralline algae (66\% Porolithon onkodes and $33 \%$ Lithophyllum flavescens), and $5 \%$ by rubble (dead coral skeletons). After collection of corals and algae (all $\sim 10 \times 10 \mathrm{~cm}$ ), they were returned to the Richard B. Gump South Pacific Research Station and attached to plastic supports using epoxy glue. Following preparation, samples were left to recover in a seawater table for 3 days.
Sediments were collected from the lagoon on the north shore, $\sim 200 \mathrm{~m}$ from the reef crest, at $2 \mathrm{~m}$ depth using 24 custom-made boxes $(0.4 \times 0.3 \times 0.3 \mathrm{~m})$. Sediment boxes were inserted into the sediment and left in situ for 4 days to allow chemical stratification in the sediment to re-establish (note that chemical stratification was not monitored) before transferring the boxes to the flumes.

The four outdoor flumes consisted of a working section measuring $5.0 \times 0.3 \times 0.3 \mathrm{~m}$. Water was re-circulated using water pumps (W. Lim Wave II $373 \mathrm{~J} \mathrm{~s}^{-1}$ ) to obtain a $10 \mathrm{~cm} \mathrm{~s}^{-1}$ flow. Flow was measured across the working section of the flume using a Nortek Vectrino Acoustic Doppler Velocimeter. At each end of the flume, seawater passed through an $88 \mathrm{~cm}$ long transition section (circular to rectangular) that housed $20 \mathrm{~cm}$ (length) flow straighteners made of stacked, $3 \mathrm{~cm}$ (inner diameter) PVC pipe, and then into a $12.5 \mathrm{~cm}$ (inner diameter) return section. Fresh sand-filtered seawater, pumped from Cook's Bay at $12 \mathrm{~m}$ depth, was dispensed continuously into the flume at $5 \mathrm{~L} \mathrm{~min}^{-1}$. Flumes experienced natural sunlight that was attenuated using fiberglass screens to maintain irradiances similar to ambient irradiances in the back reefs of Moorea (daily maximum of $\sim 1500 \mu \mathrm{mol}$ photons $\mathrm{m}^{-2} \mathrm{~cm}^{-1}$ over the incubation period determined with a $4 \pi$ quantum sensor LI-193 and a LI-COR LI-1400 meter). Temperature in the flumes was maintained at $\sim 27^{\circ} \mathrm{C}$ to match the ambient temperature in the back reef of Moorea in September-October.

\subsection{Carbonate chemistry control and measurements}

As the $p \mathrm{CO}_{2}$ in seawater flowing over the back reef of Moorea is close to open-ocean and current atmospheric values (e.g., Comeau et al., 2014a), $p \mathrm{CO}_{2}$ levels for the incubations were chosen to match ambient $p \mathrm{CO}_{2}(\sim 400 \mu \mathrm{atm})$ and the $p \mathrm{CO}_{2}$ expected in the atmosphere by the end of the present century under a pessimistic scenario of further anthropogenic activity (Representative Concentration Pathway 8.5, $1300 \mu \mathrm{atm}$; Moss et al., 2010). $p \mathrm{CO}_{2}$ in the flumes was controlled using a pH-stat (AquaController, Neptune systems, USA) that actuated the bubbling of either pure $\mathrm{CO}_{2}$ or $\mathrm{CO}_{2}$-free air into the seawater. To match the natural diel variation in $\mathrm{pH}$ in the back reef of Moorea (Hofmann et al., 2011; Comeau et al., 2014a), pH was maintained 0.1 unit lower at night (from 18:00 to 06:00) than during the day.

$\mathrm{pH}$ was measured daily using a portable $\mathrm{pH}$ meter (Orion 3-stars, Thermo-Scientific, USA) fitted with a DG 115-SC $\mathrm{pH}$ probe (Mettler Toledo, Switzerland) calibrated every other day with Tris/HCl buffers (Dickson et al., 2007). $\mathrm{pH}$ also was measured spectrophotometrically using m-Cresol dye (Dickson et al., 2007) at regular intervals. pH measured spectrophotometrically or using a $\mathrm{pH}$ electrode provided similar results with means differing $<0.01 \mathrm{pH}$ unit. Measurement of total alkalinity $\left(A_{\mathrm{T}}\right)$ was made using open-cell potentiometric titrations (Dickson et al., 2007) using $50 \mathrm{~mL}$ samples of seawater collected every 2-3 days. Titrations 
Table 1. Mean carbonate chemistry in the four flumes (F1-4) during the 8-week incubation. The partial pressure of $\mathrm{CO}_{2}\left(p \mathrm{CO}_{2}\right)$, the aragonite saturation state $\left(\Omega_{\mathrm{arag}}\right)$, and the calcite saturation state $\left(\Omega_{\text {calc }}\right)$ were calculated from $\mathrm{pH}_{\mathrm{T}}$, total alkalinity $\left(A_{\mathrm{T}}\right)$, temperature, and salinity. The values presented are mean $\pm \operatorname{SE}(n=56)$. SE for salinity was $<0.1$.

\begin{tabular}{|c|c|c|c|c|c|c|c|c|}
\hline Flume & Treatment & $\mathrm{pH}_{T}$ & $\begin{array}{l}A_{\mathrm{T}} \\
(\mu \mathrm{mol} \mathrm{kg}-1)\end{array}$ & $\begin{array}{l}p \mathrm{CO}_{2} \\
\quad(\mu \mathrm{atm})\end{array}$ & $\Omega_{\text {arag }}$ & $\Omega_{\text {calc }}$ & $\begin{array}{c}\text { Temperature } \\
\left({ }^{\circ} \mathrm{C}\right)\end{array}$ & Salinity \\
\hline $\mathrm{F} 1$ & High $p \mathrm{CO}_{2}$ & $7.603 \pm 0.008$ & $2343 \pm 1$ & $1329 \pm 28$ & $1.60 \pm 0.03$ & $2.41 \pm 0.04$ & $27.0 \pm 0.1$ & 35.9 \\
\hline $\mathrm{F} 2$ & Ambient & $8.010 \pm 0.012$ & $2339 \pm 1$ & $456 \pm 19$ & $3.49 \pm 0.07$ & $5.26 \pm 0.11$ & $26.8 \pm 0.1$ & 35.9 \\
\hline F3 & High $p \mathrm{CO}_{2}$ & $7.617 \pm 0.014$ & $2345 \pm 1$ & $1306 \pm 42$ & $1.68 \pm 0.05$ & $2.53 \pm 0.08$ & $27.1 \pm 0.1$ & 35.9 \\
\hline F4 & Ambient & $8.015 \pm 0.013$ & $2339 \pm 1$ & $451 \pm 18$ & $3.53 \pm 0.07$ & $5.32 \pm 0.11$ & $26.9 \pm 0.1$ & 35.9 \\
\hline
\end{tabular}
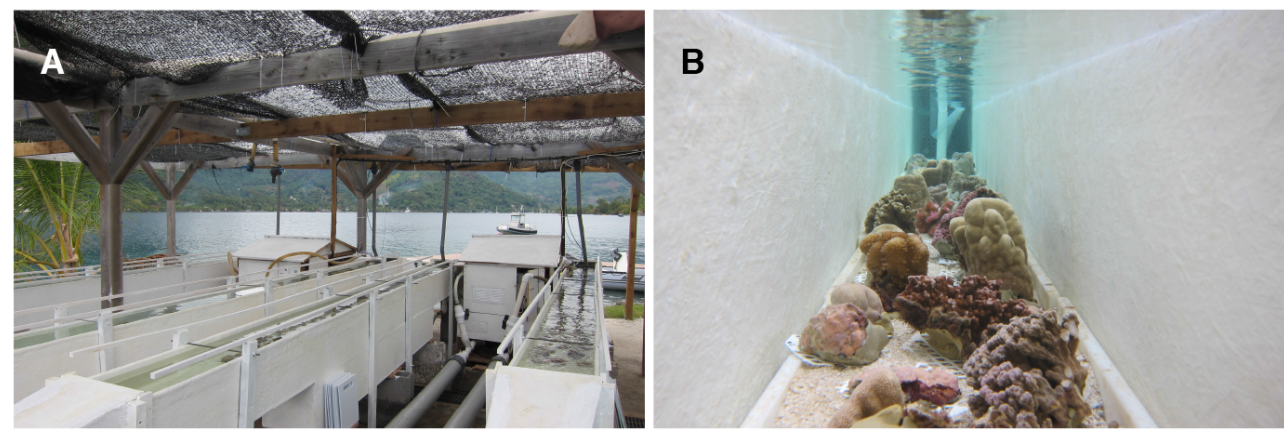

Figure 1. Photographs of the outdoor flumes. (a) The flumes consisted of a $5.00 \times 0.30 \times 0.30 \mathrm{~m}$ working section and a lower sediment chamber $(2.50 \times 0.30 \times 0.25 \mathrm{~m})$ in which sediments were maintained; together they contained $\sim 600 \mathrm{~L}$ of seawater. (b) Communities matching the average composition (in 2013) of the back reef in Moorea were constructed in the flumes.

of certified reference materials provided by A. G. Dickson (batch 122) yielded $A_{\mathrm{T}}$ values within $3.5 \mu \mathrm{mol} \mathrm{kg}{ }^{-1}$ of the nominal value $\left(\mathrm{SE}=3.1 \mu \mathrm{mol} \mathrm{kg}{ }^{-1} ; n=14\right)$. Parameters of the carbonate system in seawater were calculated using the $\mathrm{R}$ package seacarb (Lavigne and Gattuso, 2013).

\subsection{Calcification measurements and sediment analysis}

Net calcification rates were measured using the total alkalinity anomaly method (Chisholm and Gattuso, 1991), which is based on the stoichiometric relationship of two moles of $A_{\mathrm{T}}$ being removed/added for each mole of $\mathrm{CaCO}_{3}$ precipitated/dissolved. Calcification measurements were made every 7 days on the constructed community, and in the analysis of sediments alone after 7, 30, and 56 days of treatments. During incubations, the addition of seawater was stopped so that each flume operated in a closed loop; seawater samples for $A_{\mathrm{T}}$ then were taken every $3 \mathrm{~h}$ during the day and every $6 \mathrm{~h}$ at night. To maintain $A_{\mathrm{T}}$ and nutrients close to ambient levels, water in the flumes was refreshed every 3-6h for $30 \mathrm{~min}$. Regular refreshing limited changes in alkalinity during incubations to $<50-100 \mu \mathrm{mol} \mathrm{kg}^{-1}$, which corresponded to variations in aragonite saturation state $(\Omega)$ of $<0.1-0.2$. Nutrient changes in the flumes were monitored during four incubations, and the changes in nitrate and ammonium during incubations were $<2 \mu \mathrm{mol} \mathrm{L}^{-1}$. To conduct incubations with sediments alone, corals and coralline algae were removed from the flumes for $24 \mathrm{~h}$ and held in a separate tank where conditions were identical to those in the flumes. Corals and coralline algal calcification was calculated by subtracting the mean light and dark net calcification of the sediments from the community calcification. For both corals and algae, buoyant weight (Davies, 1989) was recorded before and after the 8 -week treatments and converted to dry weight to quantify the contribution of each functional group to the calcification budget. Sediment grain size of each flume was analyzed in triplicate using sediment sieves. Three vertical cross sections of sand $(\sim 600 \mathrm{~g})$ were collected from each flume sediment chamber and dried at $60^{\circ} \mathrm{C}$ to remove moisture. Sand then was sieved through five separate sediment sieves $(149,420$, $840,3360 \mu \mathrm{m})$ yielding six size class fractions for each flume $(n=3)$.

\subsection{Statistical analysis}

All analyses were performed using R software (R Foundation for Statistical Computing), and assumptions of normality and equality of variance were evaluated through graphical analyses of residuals. Calcification rates were analyzed using a repeated-measures ANOVA in which the within subject factor was time (week), $p \mathrm{CO}_{2}$ was a fixed effect, and duplicate flumes was a nested effect. 


\section{Results}

\subsection{Carbonate chemistry and organism condition}

Mean $p \mathrm{CO}_{2}$ in the four flumes during the 8-week incubation was $456 \pm 21 \mu \mathrm{atm}$ and $451 \pm 21 \mu \mathrm{atm}$ in the ambient treatments, and $1329 \pm 28 \mu \mathrm{atm}$ and $1306 \pm 41 \mu \mathrm{atm}$ in the high- $p \mathrm{CO}_{2}$ treatments ( $\left.\pm \mathrm{SE}, n=42\right) . p \mathrm{CO}_{2}$ differed between treatments (repeated-measures ANOVA, $F_{1,232}=$ 734.38, $p<0.001$ ), but there was no difference within treatments $\left(F_{2,232}=0.16, p=0.852\right)$. Communities were maintained in conditions within the flumes that were supersaturated with respect to aragonite, as $\Omega_{\text {arag }} \sim 3.5$ under ambient conditions and $\sim 1.6$ in the high $p \mathrm{CO}_{2}$ treatment.

No Pocillopora spp. and Montipora spp. colonies died during the 8-week treatments, but $10 \%$ of the Porites pooled across flumes died by the end of the experiment, regardless of treatment, because of an outbreak of corallivorous nudibranchs (Phestilla spp.), which consumed tissue of Porites spp. Most coralline algae $(\sim 70 \%)$ had died by the end of the incubation, which was likely due to sediment abrasion. No difference in mortality or bleaching was observed between treatments for corals and calcified algae.

\subsection{Community}

Net calcification was higher at ambient versus high $p \mathrm{CO}_{2}$ (Fig. 2a), both during the day and night (repeatedmeasures ANOVA, $F_{1,2}=84.9, p=0.012$ and $F_{1,2}=$ $44.9, p=0.022$, respectively); there were no differences between flumes within each treatment, so the nested factor was removed from the final analysis. At night, treatment effects were more striking than during the day, as calcium carbonate dissolution exceeded precipitation at high $p \mathrm{CO}_{2}\left(-1.6 \pm 0.9 \mathrm{gCaCO}_{3} \mathrm{~m}^{-2} \mathrm{~d}^{-1}\right)$, whereas net calcification remained positive at ambient $p \mathrm{CO}_{2}$ $\left(2.6 \pm 0.6 \mathrm{gCaCO}_{3} \mathrm{~m}^{-2} \mathrm{~d}^{-1}\right)$ (both means $\left.\pm \mathrm{SE}, \quad n=16\right)$. Calcification integrated over $24 \mathrm{~h}$ highlighted the difference between treatments $\left(F_{1,2}=869.2, p=0.001\right)$, with calcification $59 \%$ lower at high $p \mathrm{CO}_{2}$ than at ambient $p \mathrm{CO}_{2}$.

\subsection{Sediments}

Sediment grain sizes in the flumes were similar between flumes and fractionated (by weight) to $5.3 \pm 0.5 \%<149 \mu \mathrm{m}$ grain size, $56.5 \pm 1.4 \%>149 \mu \mathrm{m}$ and $<420 \mu \mathrm{m}$, $25.9 \pm 0.4 \%>420 \mu \mathrm{m}$ and $<840 \mu \mathrm{m}, 10.1 \pm 0.5 \%>840 \mu \mathrm{m}$ and $<3360 \mu \mathrm{m}$, and $2.2 \pm 0.9 \%>3360 \mu \mathrm{m}$. Net calcification of the sediments alone differed between treatments, during the day and night $\left(F_{1,2}=344.2, p=0.003\right.$ and $F_{1,2}=282.6, p=0.003$, respectively) (Fig. 2b), but there were no differences between flumes within each treatment; hence the nested factor was removed from the final analysis. Net calcification pooled among treatments was negative during the day $\left(-0.7 \pm 0.5 \mathrm{gCaCO}_{3} \mathrm{~m}^{-2} \mathrm{~d}^{-1}\right)$ and night $\left(-2.5 \pm 0.4 \mathrm{gCaCO}_{3} \quad \mathrm{~m}^{-2} \mathrm{~d}^{-1}\right)$ at high

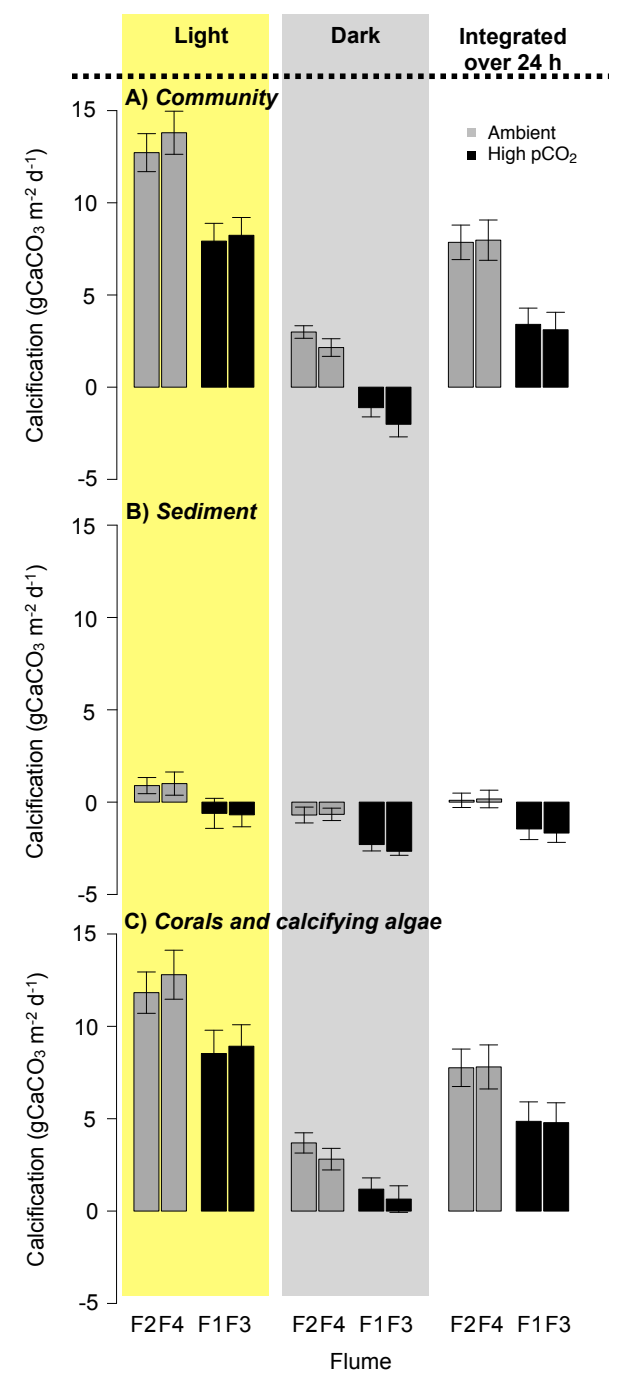

Figure 2. Calcification in the light, dark, and integrated over $24 \mathrm{~h}$ for intact communities (a), sediment (b), and corals and coralline algae (c) maintained under ambient and high $p \mathrm{CO}_{2}(\sim 1300 \mu \mathrm{atm})$. The grey bars represent the calcification measured in the ambient conditions, and the black bars are calcification in the elevated $p \mathrm{CO}_{2}$ treatment. F1, F2, F3, and F4 indicate the different flumes.

$p \mathrm{CO}_{2}$, whereas net calcification was positive during the day $\left(0.9 \pm 0.7 \mathrm{gCaCO}_{3} \mathrm{~m}^{-2} \mathrm{~d}^{-1}\right)$ and negative at night $\left(-0.6 \pm 0.8 \mathrm{gCaCO}_{3} \mathrm{~m}^{-2} \mathrm{~d}^{-1}\right)$ in the ambient treatment. When calcification was integrated over $24 \mathrm{~h}, \quad p \mathrm{CO}_{2}$ effects were significant $\left(F_{1,2}=886.5\right.$, $p=0.001)$, with dissolution exceeding precipitation at high $p \mathrm{CO}_{2} \quad\left(-1.6 \pm 0.8 \mathrm{gCaCO}_{3} \mathrm{~m}^{-2} \mathrm{~d}^{-1}\right)$ and a nearly balanced calcification budget under ambient $p \mathrm{CO}_{2}$ $\left(0.1 \pm 0.6 \mathrm{gCaCO}_{3} \mathrm{~m}^{-2} \mathrm{~d}^{-1}\right)$.

\subsection{Corals and calcifying algae}

The total net calcification of corals and calcifying algae was estimated by subtracting the mean sediment calcification 
rates from the total community calcification in each flume. Net calcification of the corals and calcifying algae differed between treatments during the day $\left(F_{1,2}=32.3, p=0.030\right)$ and night $\left(F_{1,2}=22.9, p=0.041\right)$ (Fig. $\left.2 \mathrm{c}\right)$. In contrast to the whole community and the sediments alone, net calcification of corals and calcifying algae was positive at night at high $p \mathrm{CO}_{2}\left(0.9 \pm 0.5 \mathrm{gCaCO}_{3} \mathrm{~m}^{-2}\right.$ in $\left.12 \mathrm{~h}\right)$, but it was $24 \%$ and $44 \%$ lower at high $p \mathrm{CO}_{2}$ compared to ambient $p \mathrm{CO}_{2}$ during the day and night, respectively. Net calcification integrated over $24 \mathrm{~h}$ also differed between treatments $\left(F_{1,2}=2569, p<0.001\right)$, with calcification at ambient $p \mathrm{CO}_{2}$ $29 \%$ higher than at high $p \mathrm{CO}_{2}$.

Calcification of the constructed reef communities was driven principally by corals, since their contribution to the calcification budget, based on dry weight calculated from the changes in buoyant weight, was $\sim 98 \%$ of the total (Fig. 3). Massive Porites spp. were the main contributor among the corals, with an increased contribution to the calcification budget at high $p \mathrm{CO}_{2}\left(40 \%\right.$ at ambient $p \mathrm{CO}_{2}$, and $48.5 \%$ at high $p \mathrm{CO}_{2}$, Fig. 3). In contrast, the importance of P. rus, Montipora spp., and Pocillopora spp. was reduced at high $p \mathrm{CO}_{2}$. The small contribution of coralline algae to the calcification budget was due to high mortality perhaps leading to potential dissolution during the last weeks of the incubation. Furthermore, while the ratio of planar area to surface area for crustose coralline algae is close to 1 , corals have a disproportionately large surface area : planar area ratio due to their three-dimensional structure. With such a large actual surface area, the corals made a large contribution to the calcification budget of the communities assembled in the flumes.

\section{Discussion}

Using outdoor flumes, we show that the effects of OA on coral reef communities are greater than estimates obtained by summing results obtained by incubating organisms in isolation under similar conditions and assuming their contribution to community calcification is proportional to their planar cover. Indeed, at the community level, the reduction in net calcification attributed to high $p \mathrm{CO}_{2}$ was greater than the mean reduction of $26 \%$ calculated in a recent meta-analysis of the effects of future conditions $\left(\sim 1300 \mu \mathrm{atm} p \mathrm{CO}_{2}\right)$ based on the consequences of high $p \mathrm{CO}_{2}$ on organismic calcification (Chan and Connolly, 2013). This discrepancy likely is not caused by experimental bias, as rates of net community calcification in the flumes in the ambient treatment were similar to rates measured for back-reef communities on the north shore of Moorea. For instance, in 2012 and 2013 we measured calcification rates during the day that ranged from 5 to $25 \mathrm{gCaCO}_{3} \mathrm{~m}^{-2} \mathrm{~d}^{-1}$ (R. C. Carpenter, unpublished data), which spans the rates measured in flumes during the present study (i.e., $13.9 \mathrm{gCaCO}_{3} \mathrm{~m}^{-2} \mathrm{~d}^{-1}$ in the light, Fig. 2a). Net community calcification for the back reef of Moorea in 1991 ( 19-25 $\mathrm{gCaCO}_{3} \mathrm{~m}^{-2} \mathrm{~d}^{-1}$; Gattuso et al., 1996) was also

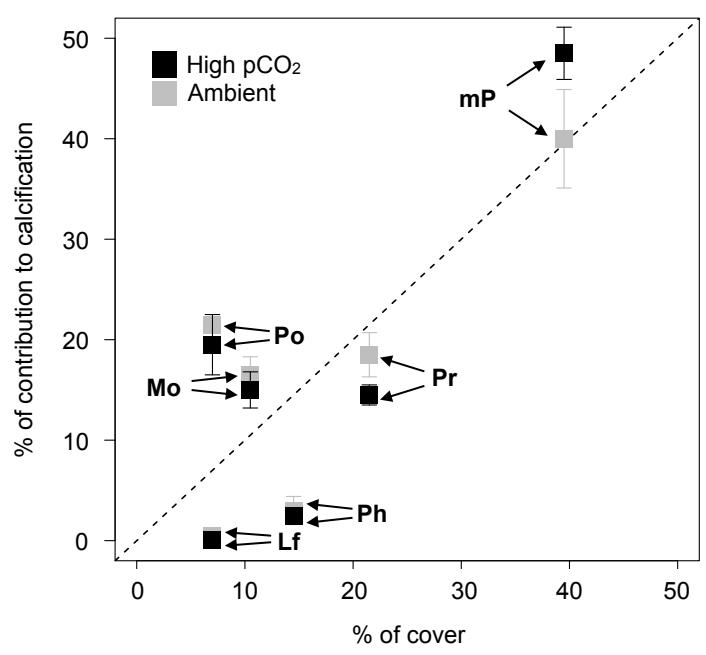

Figure 3. Relative contribution of each functional group of corals and calcifying algae to the calcification budget of communities as a function of their contribution to the planar surface area of calcifiers in the flumes. Contribution to the calcification budget was derived from the buoyant weight measurements made on each individual at the beginning and end of the 8-week incubation. The grey (ambient condition) and black (high $p \mathrm{CO}_{2}$ ) squares correspond to the mean \pm SD specific contributions of massive Porites $(\mathrm{mP})$, Porites rus (Pr), Pocillopora spp. (Po), Montipora spp. (Mo), Porolithon onkodes $(\mathrm{Ph})$, and Lithophyllum flavescens (Lf). The dashed line corresponds to a contribution to the calcification budget equivalent to the planar surface areas of calcifier in the flumes.

similar to the rates measured in the flumes (this study) and in the field as described above. Rates of calcification in the present study under ambient conditions are also similar to the $7.9 \mathrm{gCaCO}_{3} \mathrm{~m}^{-2} \mathrm{~d}^{-1}$ reported by Andersson et al. (2009) for a reef community from Kaneohe Bay (Hawaii) that was assembled and incubated in mesocosms. However, while community calcification was still positive under high $p \mathrm{CO}_{2}$ in the present study, Andersson et al. (2009) measured negative calcification (i.e., net dissolution) in their coral reef communities incubated at a $p \mathrm{CO}_{2}$ twice that of current ambient values. The differences between the present study and that of Andersson et al. (2009) may be due to methodological effects. Andersson et al. (2009) manipulated pH through acid additions (we used $\mathrm{CO}_{2}$ bubbling) and also used a different assemblage of species and sediments in dissimilar proportions compared to the present study.

The discrepancy in the evaluation of the effects of high $p \mathrm{CO}_{2}$ at the community level (the present study) versus organismic level (previous studies) was the result of dissolution of sediments that represented up to $50 \%$ of the decrease in calcification at high $p \mathrm{CO}_{2}$. Increased dissolution of sediments at high $p \mathrm{CO}_{2}$ likely was caused by the reduction of the seawater saturation state in the flumes, as we did not detect any difference in respiration and photosynthesis under elevated $p \mathrm{CO}_{2}$ (results not shown) that could also affect 
sediment dissolution (Andersson and Gledhill, 2013). Our results reveal the sensitivity of carbonate sediments to dissolution at elevated $p \mathrm{CO}_{2}$, and they are in agreement with a recent manipulative experiment conducted on Heron Island (Australia), where dissolution of in situ areas of sand $(1.7 \mathrm{~m}$ depth) exceeded precipitation at $p \mathrm{CO}_{2}>500 \mu \mathrm{atm}$ (Cyronak et al., 2013a). During a mesocosm experiment, Dove et al. (2013) also demonstrated that a pH of 7.7 caused a change in sediment granularity to favor small-grained (i.e., $\leq 1 \mathrm{~mm}$ ) sediments as a result of dissolution or increased bioerosion of larger grains. In this case, bioerosion was more likely than dissolution, as dissolution would favor a loss of the smallest grains as a result of their higher surface-area-tovolume ratio. Size-frequency distribution of sediment grain was not different between treatments at the end of our incubations and therefore is unlikely to have affected the treatment effects we detected. Sensitivity of coral reef communities to dissolution has been shown previously for communities constructed in mesocosms in Hawaii, where dissolution $\left(-3.6 \mathrm{mmol} \mathrm{CaCO}_{3} \mathrm{~m}^{-2} \mathrm{~h}^{-1}\right)$ was detected at night when $\mathrm{CO}_{2}$ levels in the mesocosm were equivalent to 2-fold $p \mathrm{CO}_{2}$ in ambient air (Andersson et al., 2009). In this case, dissolution was attributed to the thin layer of sediment that accumulated at the bottom of the mesocosms (Andersson et al., 2009).

In addition to chemical dissolution occurring in the communities constructed in the present study, we cannot exclude the possibility that at least some of the apparent community dissolution was caused by enhanced bioerosion, which previously has been shown to occur when blocks of Porites lobata are incubated under $750 \mu$ atm $p \mathrm{CO}_{2}$ for 3 months (Tribollet et al., 2009). In future work it will be important to census the fragments of coral and rock to quantify the presence of bioeroders and their relative contribution to dissolution under ambient and OA conditions.

When the effect of sediment dissolution was subtracted from the overall net calcification rate for the communities assembled in our flumes, corals and coralline algae alone accounted for a decrease in net calcification of $29 \%$ over $24 \mathrm{~h}$ at elevated $p \mathrm{CO}_{2}$ versus ambient $p \mathrm{CO}_{2}$. Such a decrease falls within the range of values we have previously reported for organismic effects of high $p \mathrm{CO}_{2}$, in which the calcification rates of 16 calcifiers in Moorea declined 0-40\% at $1300 \mu \mathrm{atm} p \mathrm{CO}_{2}$ compared to ambient $p \mathrm{CO}_{2}$ (Comeau et al., 2013, 2014b). It is also within the range of the predicted changes for calcification of corals under a tripling of $p \mathrm{CO}_{2}$ (relative to present values) estimated by meta-analysis (i.e., a $\sim 26 \%$ reduction; Chan and Connolly, 2013). The proportional decrease (i.e., $\sim 29 \%$ ) in calcification rate for corals and coralline algae recorded in the present study under a tripling of present $p \mathrm{CO}_{2}$ alone supports the validity of our experimental approach, which assumes that calcification of macrocalcifiers is equal to the difference between net sediment calcification and net community calcification. This "subtraction method" for calculating the calcification rate of corals and coralline algae included in community experiments has some limitations, as it assumes that the calcification of the sediments and the macrocalcifiers are independent. This assumption might be violated if, for example, sediment dissolution locally enhances total alkalinity that could favor calcification of nearby macrocalcifiers. Testing for such feedback mechanisms among the different compartments of the communities we built was beyond the scope of the present study, but it will be important to consider such effects in future experiments.

Our results demonstrate the suitability of large outdoor flumes for investigating the responses of coral reef communities to OA. Similar rates of calcification in the field and in the flumes suggest that the communities assembled in the flumes effectively mimicked both the biological communities and the physical and chemical conditions characterizing the back reef of Moorea. The ability to create ecologically relevant flow conditions in the flumes is likely to be especially important for establishing ecological relevance, as flow is critical in modulating mass transfer and metabolism of coral reef organisms (Atkinson and Gilmer, 1992; Carpenter and Williams, 2007; Comeau et al., 2014c). In the case of stony corals, for example, high flow speeds are suspected to enhance coral calcification by favoring proton export from coral tissue through boundary layers (Jokiel, 2011; Jokiel et al., 2014); for coralline algae, high flow speeds might increase sensitivity to OA by reducing the capacity to maintain high $\mathrm{pH}$ in the diffusion boundary layer adjacent to the algal thallus (Cornwall et al., 2013, 2014).

\section{Conclusions}

The present results suggest that, despite a reduction in calcification, calcifying reef organisms may maintain net positive calcification under $p \mathrm{CO}_{2}$ as high as $1300 \mu \mathrm{atm}$. However, at the scale of coral reef communities in back-reef habitats, community net calcification will be affected strongly and negatively, at least for reefs similar in community structure to those in Moorea in 2013. The present experiments demonstrate the importance of living organisms on benthic surfaces in maintaining a positive balance between precipitation and dissolution of calcium carbonate. Whereas several reefs around the world are already at the threshold between precipitation and dissolution of calcium carbonate (Silverman et al., 2009, 2014), the susceptibility of coral reefs to net dissolution in the future likely will be linked directly to the proportion of the reef covered by macrocalcifiers and sediments. In addition to dissolution, it also is possible that coral reefs will be exposed to increased bioerosion at high $p \mathrm{CO}_{2}$ (Wisshak et al., 2012; Crook et al., 2013) that will decrease the integrity of the carbonate framework. In addition to the direct effects of OA on reef builders, the associated loss of three-dimensional framework might impact a large variety of marine organisms by reducing habitat complexity 
and the availability of refuges (Fabricius et al., 2014). Our results suggest that, under OA conditions anticipated by the end of the current century, at least some tropical corals and calcifying algae will persist, but the function of the coral reef community as a net precipitator of calcium carbonate and as a physical structure to protect coasts against erosion (Ferrario et al., 2014) will be challenged.

Author contributions. S. Comeau designed and performed experiments, analyzed data, and wrote the paper; C. Lantz performed experiments and wrote the paper; B. Carpenter and P. Edmunds designed experiments, analyzed data, and wrote the paper.

Acknowledgements. We dedicate this paper to Marlin Atkinson, who pioneered the use of large outdoor flumes for the analysis of coral community metabolism, and whose work inspired our science and the present experiments. This study was funded by the National Science Foundation (OCE 10-41270) and the Moorea Coral Reef LTER (OCE 04-17413 and 10-26852). This is contribution number 225 of the CSUN Marine Biology Program.

Edited by: H. Niemann

\section{References}

Atkinson, M. J. and Bilger, R. W.: Effects of water velocity on phosphate uptake in coral reef-flat communities, Limnol. Oceanogr., 37, 273-279, 1992.

Andersson, A. J. and Gledhill, D.: Ocean acidification and coral reefs: effects on breakdown, dissolution, and net ecosystem calcification, Ann. Rev. Mar. Sci., 5, 321-348, 2013.

Andersson, A. J., Bates, N. R., and Mackenzie, F. T.: Dissolution of carbonate sediments under rising $p \mathrm{CO}_{2}$ and ocean acidification: observations from Devil's Hole, Bermuda, Aquatic. Geochem., 13, 237-264, 2007.

Andersson, A. J., Kuffner, I. B., Mackenzie, F. T., Jokiel, P. L., Rodgers, K. S., and Tan, A.: Net Loss of $\mathrm{CaCO}_{3}$ from a subtropical calcifying community due to seawater acidification: mesocosm-scale experimental evidence, Biogeosciences, 6 , 1811-1823, doi:10.5194/bg-6-1811-2009, 2009.

Atkinson, M. J. and Bilger, R. W.: Effects of water velocity on phosphate uptake in coral reef-flat communities, Limnol. Oceanogr., 37, 273-279, 1992.

Carpenter, R. C. of Moorea Coral Reef LTER: MCR LTER: Coral Reef: Long-term population and community dynamics: benthic algae and other community components, ongoing since 2005, knb-lter-mcr.8.27, available at: http://metacat.lternet.edu/ knb/metacat/knb-lter-mcr.8.27/lter, 2014.

Carpenter, R. C. and Williams, S. L.: Mass transfer limitation of photosynthesis of coral reef algal turfs, Mar. Biol., 151, 435-450, 2007.

Chan, N. C. S. and Connolly, S. R.: Sensitivity of coral calcification to ocean acidification: a meta-analysis, Glob. Change Biol., 19, 282-290, 2013.
Chisholm, J. R. M. and Gattuso, J.-P.: Validation of the alkalinity anomaly technique for investigating calcification and photosynthesis in coral reef communities, Limnol. Oceanogr., 36, 1232 1239, 1991.

Comeau, S., Edmunds, P. J., Spindel, N. B., and Carpenter, R. C.: The responses of eight coral reef calcifiers to increasing partial pressure of $\mathrm{CO}_{2}$ do not exhibit a tipping point, Limnol. Oceanogr., 58, 388-398, 2013.

Comeau, S., Edmunds, P. J., Spindel, N. B., and Carpenter, R. C.: Diel $p \mathrm{CO}_{2}$ oscillations modulate the response of the coral Acropora hyacinthus to ocean acidification, Mar. Ecol. Prog. Ser., 501, 99-111, 2014a.

Comeau, S., Edmunds, P. J., Spindel, N. B., and Carpenter, R. C.: Fast coral reef calcifiers are more sensitive to ocean acidification in short-term laboratory incubations, Limnol. Oceanogr., 59, 1081-1091, 2014b.

Comeau, S., Edmunds, P. J., Lantz, C. A., and Carpenter, R. C.: Water flow modulates the response of coral reef communities to ocean acidification, Scientific Reports, 4, 6681, doi:10.1038/srep06681, 2014c.

Cornwall, C. E., Hepburn, C. D., Pilditch, C. A., and Hurd, C. L.: Concentration boundary layers around complex assemblages of macroalgae: Implications for the effects of ocean acidification on understory coralline algae, Limnol. Oceanogr., 58, 121-130, 2013.

Cornwall, C. E., Boyd, P. W., McGraw, C. M., Hepburn, C. D., Pilditch, C. A., Morris, J. N., Smith, A. M., and Hurd, C. L.: Diffusion boundary layers ameliorate the negative effects of ocean acidification on the temperate coralline macroalga Arthrocardia corymbosa, PLoS One, 9, e97235, doi:10.1371/journal.pone.0097235, 2014.

Crook, E. D., Cohen, A. L., Rebolledo-Vieyra, M., Hernandez, L., and Paytan, A.: Reduced calcification and lack of acclimatization by coral colonies growing in areas of persistent natural acidification, P. Natl. Acad. Sci., 110, 11044-11049, 2013.

Cyronak, T., Santos, I. R., and Eyre, B. D.: Permeable coral reef sediment dissolution driven by elevated $p \mathrm{CO}_{2}$ and pore water advection, Geophys. Res. Lett., 40, 4876-4881, $2013 \mathrm{a}$.

Cyronak, T., Santos, I. R., McMahon, A., and Eyre, B. D.: Carbon cycling hysteresis in permeable carbonate sands over a diurnal cycle: implications for ocean acidification, Limnol. Oceanogr., 58, 131-143, $2013 b$.

Davies, P. S.: Short-term growth measurements of corals using an accurate buoyant weighing technique, Mar. Biol., 101, 389-395, 1989.

Dickson, A. G., Sabine, C. L., and Christian, J. R. (Eds.): Guide to best practices for $\mathrm{CO}_{2}$ measurements, PICES Special Publication, 3, 191 pp., 2007.

Dove, S. G., Kline, D. I., Pantos, S., Angly, F. E., Tyson, G. W., and Hoegh-Guldberg, O.: Future reef decalcification under a business-as-usual $\mathrm{CO}_{2}$ emission scenario, P. Natl. Acac. Sci., 110, 15342-15347, 2013.

Edmunds, P. J. (of Moorea Coral Reef LTER): MCR LTER: Coral Reef: Long-term population and community dynamics: corals, knb-lter-mcr.4.31, available at: http://metacat.lternet.edu/ knb/metacat/knb-lter-mcr.4.31/lter, 2014.

Erez, J., Reynaud, S., Silverman, J., Schneider, K., and Allemand, D.: Coral calcification under ocean acidification and global change, in: Coral reefs: An ecosystem in transition, edited by: 
Dubinsky, Z. and Stambler, N., Springer, Germany, 151-176, 2011.

Fabricius, K. E., Langdon, C., Uthicke, S., Humphrey, C., Noonan, S., De'ath, G., Okazaki, R., Muehllehner, N., Glas, M. S., and Lough, J. M.: Losers and winners in coral reefs acclimatized to elevated carbon dioxide concentrations, Nature Clim. Change, 1, 165-169, 2011.

Fabricius, K. E., De'ath, G., Noonan, S., and Uthicke, S.: Ecological effects of ocean acidification and habitat complexity on reefassociated macroinvertebrate communities, P. Roy. Soc. B-Bio. Sci., 281, 20132479, doi:10.1098/rspb.2013.2479, 2014.

Feely, R. A., Sabine, C. L., Lee, K., Berelson, W., Kleypas, J., Fabry, V. J., and Millero, F. J.: Impact of anthropogenic $\mathrm{CO}_{2}$ on the $\mathrm{CaCO}_{3}$ system in the oceans, Science, 305, 362-366, 2004.

Ferrario, F., Beck, M. W., Storlazzi, C. D., Micheli, F., Shepard, C. C., and Airoldi, L.: The effectiveness of coral reefs for coastal hazard risk reduction and adaptation, Nature Comm., 5, 3794, 2014.

Gattuso, J.-P., Pichon, M., Delesalle, B., Canon, C., and Frankignoulle, M.: Carbon fluxes in coral reefs. I. Lagrangian measurement of community metabolism and resulting air-sea $\mathrm{CO}_{2}$ disequilibrium, Mar. Ecol. Prog. Ser., 145, 109-121, 1996.

Hoegh-Guldberg, O., Mumby, P. J., Hooten, A. J., Steneck, R. S., Greenfield, P., Gomez, E., Harvell, C. D., Sale, P. F., Edwards, A. J., Caldeira, K., Knowlton, N., Eakin, C. M., Iglesias-Prieto, R., Muthiga, N., Bradbury, R. H., Dubi, A., and Hatziolos M. E.: Coral reefs under rapid climate change and ocean acidification, Science, 318, 1737-1742, 2007.

Hofmann, G. E., Smith, J. E., Johnson, K. S., Send, U., Levin, L. A., Micheli, F., Paytan, A., Price, N. N., Peterson, B., Takeshita, Y., Matson, P. G., Derse Crook, E., Kroeker, K. J., Gambi, M. C., Rivest, E. B., Frieder, C. A., Yu, P. C., and Martz, T. R.: Highfrequency dynamics of ocean $\mathrm{pH}$ : a multi-ecosystem comparison, PLoS ONE, 6, e28983. doi:10.1371/journal.pone.0028983, 2011.

Jokiel, P. L.: The reef coral two compartment proton flux model: A new approach relating tissue-level physiological processes to gross corallum morphology, J. Exp. Mar. Biol. Ecol., 409, 1-12, 2011.

Jokiel, P. L., Rodgers, K. S., Kuffner, I. B., Andersson, A. J., Cox, E. F., and Mackenzie, F. T.: Ocean acidification and calcifying reef organisms: a mesocosm investigation, Coral Reefs, 27, 473-483, 2008.

Jokiel, P. L., Jury, C. P., and Rodgers, K. S.: Coral-algae metabolism and diurnal changes in the $\mathrm{CO}_{2}$-carbonate system of bulk sea water, PeerJ, 2, e378, doi:10.7717/peerj.378, 2014.

Kleypas, J. and Yates, K.: Coral reefs and ocean acidification, Oceanogr., 22, 108-117, 2009.
Kline, D. I., Teneva, L., Schneider, K., Miard, T., Chai, A., Marker, M., Headley, K., Opdyke, B., Nash, M., Valetich, M., Caves, J. K., Russell, B. D., Connell, S. D., Kirkwood, B. J., Brewer, P., Peltzer, E., Silverman, J., Caldeira, K., Dunbar, R. B., Koseff, J. R., Monismith, S. G., Mitchell, B. G., Dove, S., and Hoegh-Guldberg, O.: A short-term in situ $\mathrm{CO}_{2}$ enrichment experiment on Heron Island (GBR), Scientific Reports, 2, 413, doi:10.1038/srep00413, 2012.

Lavigne, H. and Gattuso, J.-P.: seacarb, seawater carbonate chemistry with R. R package version 2.4.10, available at: http:// CRAN.R-project.org/package=seacarb, 2013.

Leclercq, N., Gattuso, J.-P., and Jaubert, J.: Primary production, respiration, and calcification of a coral reef mesocosm under increased $\mathrm{CO}_{2}$ partial pressure, Limnol. Oceanogr., 47, 558-564, 2002.

Moss, R. H., Edmonds, J. A., Hibbard, K. A., Manning, M. R., Rose, S. K., VanVuuren, D. P., Carter, T. R., Emori, S., Kainuma, M., Kram, T., Meehl, G. A., Mitchell, J. F., Nakicenovic, N., Riahi, K., Smith, S. J., Stouffer, R. J., Thomson, A. M., Weyant, J. P., and Wilbanks, T. J.: The next generation of scenarios for climate change research and assessment, Nature, 463, 747-756, 2010.

Shamberger, K. E. F., Cohen, A. L., Golbuu, Y., McCorkle, D. C., Lentz, S. J., and Barkley, H. C.: Diverse coral communities in naturally acidified waters of a Western Pacific reef, Geophys. Res. Lett., 41, 499-504, 2014.

Silverman, J., Lazar, B., Cao, L., Caldeira, K., and Erez, J.: Coral reefs may start dissolving when atmospheric $\mathrm{CO}_{2}$ doubles, Geophys. Res. Lett., 36, L05606, doi:10.1029/2008GL036282, 2009.

Silverman, J., Schneider, K., Kline, D. I., Rivlin, T., Rivlin, A., Hamylton, S., Lazar, B., Erez, J., and Caldeira, K.: Community calcification in Lizard Island, Great Barrier Reef: A 33 year perspective, Geochim. Cosmochim. Acta, 144, 72-81, 2014.

Takahashi, A. and Kurihara, H.: Ocean acidification does not affect the physiology of the tropical coral Acropora digitifera during a 5-week experiment, Coral Reefs, 32, 305-314, 2013.

Tribollet, A., Godinot, C., Atkinson, M., and Langdon, C.: Effects of elevated $p \mathrm{CO}_{2}$ on dissolution of coral carbonates by microbial euendoliths, Global Biogeochem. Cy., 23, GB3008, doi:10.1029/2008GB003286, 2009.

Wisshak, M., Schönberg, C. H. L., Form, A., and Freiwald, A.: Ocean acidification accelerates reef bioerosion, PLoS One, 7, e45124, doi:10.1371/journal.pone.0045124, 2012.

Yates, K. K. and Halley, R. B.: $\mathrm{CO}_{3}^{2-}$ concentration and $p \mathrm{CO}_{2}$ thresholds for calcification and dissolution on the Molokai reef flat, Hawaii, Biogeosciences, 3, 357-369, doi:10.5194/bg-3-3572006, 2006. 